\title{
IMPROVING ABILITY TO SPEAK MOTHER TOUNGE THROUGH USE OF MINANGKABAU CREATION
}

\author{
Elindra Yetti ${ }^{1}$, Vivi Anggraini ${ }^{2}$ Hapidin $^{3}$. \\ State University of Jakarta \\ elindrayetti@unj.ac.id \\ vivianggaraini@gmail.com \\ hapidin@gmail.com
}

\begin{abstract}
This study aims to describe the process and learning outcomes through the use of song creation Minangkabau in improving the ability to speak the child's mother. This research is conducted in TK Nurul Hidayah., Bukittinggi- West Sumatra in January until February 2017. The subjects were students group B were 17 children. This study uses research methods Action research, from comprising: a) planning, b) actions and observations, c) reflection. Conducted over 16 sessions that are divided into two cycles. Data was collected through tests, observations, interviews and documentation study. Data analysis techniques used in this research is the analysis of qualitative and quantitative data. Quantitative data analysis used to determine the percentage of children's ability to speak their mother tongue after the action. the results showed an increase in children after learning to use the song Minangkabau creations. pre-actions are performed to determine the percentage of children's mother tonge by 47, 43\%, increased to $68.38 \%$ after the cycle for the First, and increased to 87, 50\% after the second cycle. The ability to speak their mother tongue can be developed through the use of song creation Minangkabau, where the song creations Minangkabau can attract children to use their imagination so that he is able to express ideas. Minangkabau creations song is a fun activity for young children.
\end{abstract}

Keywords: Speaking Mother Tounge, Creatif Song Of Minangkabau, Actions Research

Early Childhood Education (PAUD) is organized with the aim to facilitate the growth and development of children as a whole. Early childhood provides opportunities for children to develop the personality and potential to the fullest. Therefore, PAUD institutions provide various activities that can develop various aspects of development such as cognitive, language, social, emotional, physical and motor.

Based on the government regulation, awareness and the role of the community regarding the importance of early childhood as the foundation and preparation prior to the child's primary school is needed. Age 4-6 years is an important time for children to get education. In order for the child to be able to 
show good and desired attitudes by parents, educators, friends and society, the child needs one of the most important things: the ability to express feelings, ideas, and thoughts through speaking.

Expressing everything that is in our minds through speech will make it easier for people to understand and understand exactly what will be done. The mother tongue is the first language accepted by the child. The use of the mother tongue (local language) in education is regulated in the Law of the Republic of Indonesia number 20 Year 2003 article 34 paragraph 2 that: "1) Indonesian as the language of the State became the language of instruction in national education. 2) Regional languages can be used as a medium of instruction in the early stages of education if necessary in the delivery of specific knowledge and / or skills. 3) Foreign language can be used as an introduction to a particular educational unit to support the ability of foreign language learners.

Based on some results from the above research can know that previous research proves about the use of songs that are applied to children of kindergarten age. The song is something fun and can add a child's vocabulary, so the ability to speak and communicate the child can be developed optimally. It is also stated that the importance of mother tongue is developed in early childhood education, where the mother tongue is closely related to short-term memory that plays an important role in the development of academic skills and oral language skills. However, there has been no research on improving the ability to speak the mother tongue through the use of Minangkabau creations songs. This research is different from previous research, where researchers used self-created creations by researchers who adapted to the characteristics of children and the local environment, then the lyrics of the song using Minangkabau language. This is more interesting when researchers use keyboard instruments so that will increasingly make children interested in the learning process.

Based on the observation in the field that occurred in the group B TK Nurul Hidayah Bukittinggi seen the ability to speak low children. Observations conducted in Nurul Hidayah kindergarten showed that: 1) $76.47 \%$ Children have not been able to pronounce the mother tongue correctly, Child has not mastered the mother tongue (Minangkabau local language) according to the rules of speech of Minangkabau people (kato nan ampek ). 2) $82.35 \%$ of children have not been able to use varied vocabulary. 3) $88.25 \%$ The child has not been able to express his ideas, communicate, still shy, just answer a word and need a question Over and over again when the teacher asks and has not been able to pronounce the word clearly. Children are less able to interact with friends and teachers. 4) 76, 47\% Children are less able to express expression while doing activities.

Based on the relevant research and the facts of problems in the field that has been described, it is necessary to conduct research "Improved the ability to speak the mother tongue through the use of songs creations Minangkabau in children group B TK Nurul Hidayah". 


\section{Mother Language Speaking Ability}

Speaking is one of the most important and influential aspects of other children's language development such as reading and writing.

Hurlock (1978: 176) presents two criteria used to measure the ability to speak children: (1) the child must know the meaning of the word used and be able to relate it to the object it represents; (2) the child must recite his words so that others can easily understand them. Children understand these words not because they have often heard or guessed.

Stephen J. Gaies (2013: 22) states that: the first language acquisition is formed and guided by innate neurological structures and cognitive tendencies to learn the language that is the unique genetic wakaf of humans that every child has. Learning a language does not, as the behaviorist learning theory explains it, only the accumulation of a series of automatic stimulus-response associations, the process by which student participation is limited to imitation, the formation of conscious habits based on external strengthening is differential and reinforced by practice, and some unspecified forms Stimulus generalization. The process of acquiring the first language eventually ends with the achievement of the child from the systematic rules of linguistic / community competence in general.

The study proposed by Zaliha Yazici, et. Al (2010: 261) states that: The above definition of the mother tongue or the first language takes place from birth with parents and close family. The ability of the mother language affects the ability to learn in a second language. Competence as children is raised in their home country.

According to Jane K. Lartecel, et al (2014: 5) states that: The use of mother tongue in multilingual learning affects the way students learn. Implementation strategy implementation of learning mother tongue - Based on learning in multilingual setting. Based on the strategies used by teachers in the implementation of the mother tongue, learning is based in multilingual settings, several themes emerge. These themes are: (a) determining the targets or objectives of the use of the mother tongue, (b) the benefits of multilingual learning, (c) the utilization of lingua-franca, (d) the design of teaching materials written in the mother tongue, (e) the repetition of learning, And (f) the use of motivation in the mother tongue. Means from the opinion above states that in the process of learning the mother tongue should be tailored to the theme, the theme includes learning objectives, learning benefits, learning design and learning activities it is very influential on the acquisition of the mother tongue.

Navis (1984: 101) adds that in the Minangkabau language there is a word or style of kato that is; Some kind of language or daily manners between fellow Minang people in accordance with their social status. From a collection of five expert opinions, on the theory of the ability to speak the mother tongue (Minangkabau language) can be concluded that: Ability Speaking the mother 
tongue is a capability in expressing the mind through a meaningful Minangkabau language in accordance with the Minangkabau society's communication rules set out in "kato nan ampek" which include the following aspects: (1) pronunciation (2) vocabulary mastery, (3) the delivery of ideas, (4) disclosure of feelings.

The song is a composition of tone or voice in sequence, combination, and temporal relationship (usually accompanied by a musical instrument) to produce musical compositions that have aided and sustained (humming rhythm). Songs can be sung solo, two (duets), three (trio) or crowded (khoir).

Mei-Ying Liao, et al (2014: 144) reveals that; Singing plays an important role for the development of children's music and education in their kindergarten experience at the age of 5-6 years. Although Kindergarten teachers have limited ability to teach music, singing is one of the most dominant music activities used in kindergarten. Songs and singing are highly recommended as materials and learning process in kindergarten class. Singing is an activity that enhances developmental skills.

Patrick D. Walton (2014: 54) states that: a song basically begins with rhythm. Learning to sing a song is very easy for children if words end in rhymes, if there is a strong rhythm or beat, and if there are some words that are easy to remember. Minangkabau creations song is one of the alternatives that researchers use to solve the problem of improving the ability to speak the mother tongue of the child.

In Minangkabau creations song is not just singing songs Minangkabau, but the song creates it into something interesting. The use of music and motion beats which constitute a unity of beautiful harmonization, which in it stores the meaning and information to be conveyed through the Minangkabau language. With a view to improving the ability to speak Minangkabau continues to be local characteristics and still preserved its existence by the Minangkabau community itself, through the song creation Minangkabau.

Derya Arslan (2015: 2) states that: one of the activities undertaken in order to increase phonological awareness is to sing a song. Song is one of the important tools used in education, especially in language teaching. Priska et al (2013: 2), states as follows: Song is a verbal communication medium that has meaning. Likewise with the process of creating lyrics in Minang songs. The song Minang is just a title for songs from Minangkabau or West Sumatra. Because of the influence of dialect, Minangkabau songs are often referred to as Minang songs only. From here it is known that actually Minang song is a kind of regional song is not folk song (folk song). Regional songs reflect the Minangkabau cultural norms and values.

From the expert opinion about the song creations can be synthesized Minangkau Minangkabau song is a process of renewal of artworks creation songs Minangkabau both existing and fusion of existing works with not separate from the cultural identity of Minangkabau. 


\section{METHOD}

This research method is action research. Myrnawati (2012: 20) explains action research is one of the strategic ways for educators to improve and / or improve education services in the context of classroom learning. Data collection technique used in this research is non test. Non-test techniques used to obtain data about the implementation of action and data of children's speaking ability (related variables) is observation. Observations used are participant observations, in which observers participate in activities undertaken by subjects who are researched or observed as if they are part of them.

The design of action intervention / design of this research cycle uses Kemmis and MC Taggart models based on: (1) planning, (2) action / observation, (3) reflection.

Quantitative and qualitative data analysis techniques. Quantitative data analysis is presented in the form of tables and graphs. While the qualitative data analysis using Miles and Haberman method, which consists of data reduction phase, data display and data verification (1992: 16-20).

\section{RESULTS AND DISCUSSION}

Based on the results of preliminary observations indicate there are some of the children whose ability to speak the mother tongue is still low. This is seen from the child less want to express his ideas, the child difficult to pronounce the vocabulary of Minangkabau language, the child is often inappropriate when pronouncing the Minangkabau language vocabulary this is due to lack of vocabulary mastery, and the child is less able to express expression.

Pre Cycles

Early assays of mother tongue ability can be identified as follows:

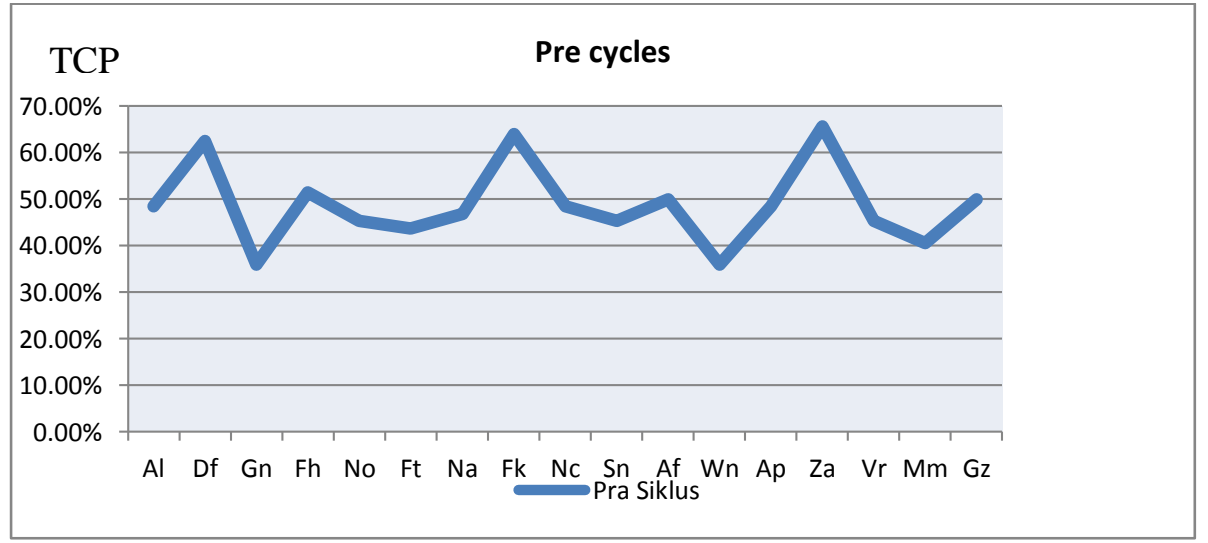

Graph 1: Pre-Cycle Pronunciation Early Math Language Ability Results 
From the pre-cycle data shows the initial scores of mother tongue ability seen the percentage of initial score as follows: Al 48.44\%, Df 62.5\%, Gn 35.94\%, Fh $51.56 \%$, No 45.31\%, Ft 43.75\%, Na 46.86\%, Fk $64.06 \%$ Nc $48.44 \%$, Sn $45.31 \%$, Af 50\%, Wn 35.94\%, Ap 48.44\%, Za 65.63\%, Vr 45.31\%, Mm 40.63\%, and $\mathrm{Gz} 50 \%$. While the average percentage of about $48.71 \%$. Thus the data showing the percentage of the ability to speak the native language of students of group B kindergarten in pre-cycle that has a higher percentage than the average of other children only amounted to 6 (six) children. The highest percentage of the highest of the overall aspects of the pre-cycles pre-cycle rating score of $65.63 \%$ owned by Za. Based on the observation data in the pre-cycle above, which has been exposed through qualitative and quantitative data, so that researchers and collabators concluded the necessary action is designed and is expected to improve the ability to speak the mother tongue of the child. The action is agreed to use Minangkabau creations songs, because children will be more interested in the song and music faster.

\section{Cycle I}

Based on the observation of mother tongue speaking ability of child in cycle 1 seen bebebrapa children look to develop as expected, but most of speech ability have not increased as expected. As a large child still needs to improve the ability to speak the mother tongue again, especially the vocabulary pronunciation and disclosure of the child's ideas. The average score achievement to know the progress of the ability to speak the mother tongue on the cycle 1 . The percentage of scores achieved by children is as follows: Al 75\%, Df $84.38 \%$, Gn 51.56\%, Fh 68.75\%, No. 60.95\%, Ft 65.63\%, Na 67.19\%, Fk 81.25\%, Nc 60.94\%, Sn 68.75\%, Af $60.06 \%$, Wn $67.19 \%$, Ap $54.69 \%$, Za $81.25 \%$, Vr 75\%, Mm 71.86\%,And Gz $56.25 \%$. And the average score reached $67.92 \%$.

The percentage of the ability to speak the mother tongue at the end of cycle 1 can be seen in the following graph:

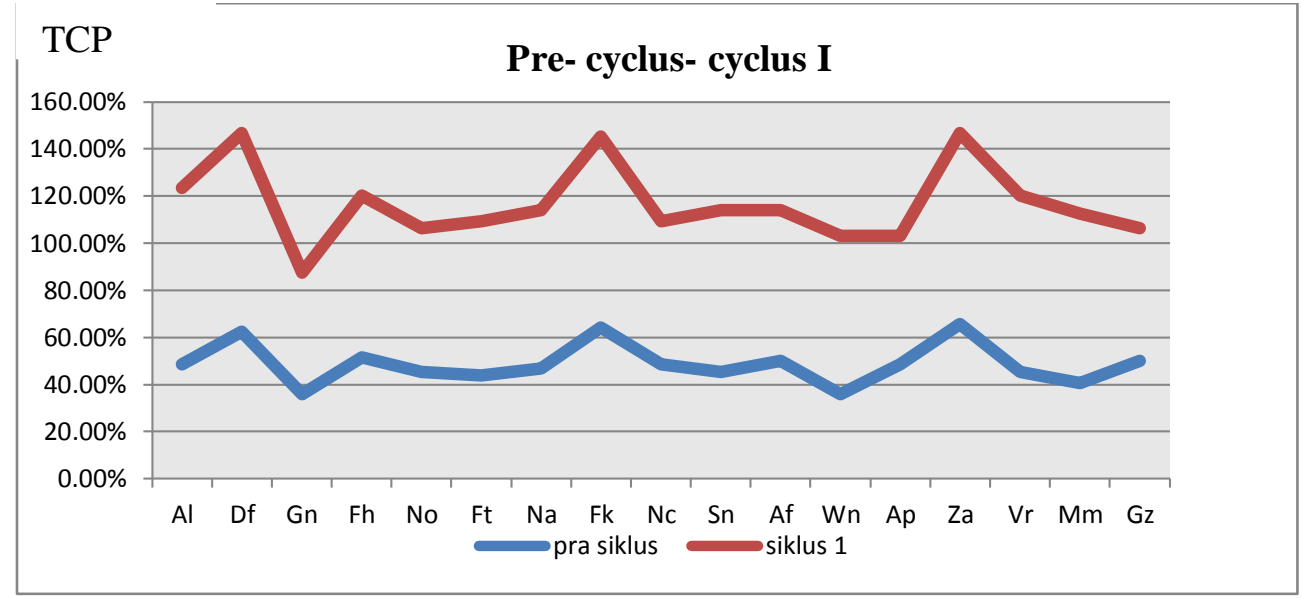

Graph 2: Graph of Outcome Results of Mother Language Language Speaking Ability In Cycle I 
Based on the graphic visualization it shows the improvement of the overall speaking ability of the whole mother language experienced during cycle 1 . There are 6 children who have percentage 48,71\% Is Df 62.5\%, Fh 51.56\%, Fk 64.06\%, $\mathrm{Nc} 48.44 \%$, Af $50 \% \mathrm{Za} 65.63 \%$, and Gz 50\%. While in cycle 1 there are 8 children who have percentage above the average class $67.92 \%$ is $\mathrm{Al} 75 \%$, Df $84.38 \%$, Fh 68.75\%, Fk 81.25\%, Sn 68.75\%, Wn 67.19\%, Za 81.25\%, Vr 75\%, Mm 71.68\%. Of these increases only 5 (five) children achieved a minimum percentage score of $75 \%$ (TCP / level of development achievement), ie Al 75\%, Df 84.38\%, Fk $81.25 \%$, Za 81.5 and $\operatorname{Vr} 75 \%$. In other words, only $29.41 \%$ of students who achieved a TCP increase of $75 \%$ with the criteria according to Mills by $71 \%$. Thus the percentage of improvement described above indicates that there are still things that need to be improved to maximize the achievement of success criteria. Therefore, it is necessary to implement the second cycle so that it will maximize learning in improving the mother tongue.

\section{Cycle II}

The results of the observations of the implementation of cycle 2 in the implementation can be seen from the table of action monitoring instruments that serve as the basis of action monitoring. The results of the 2 nd cycle action monitoring instrument indicate that the Minangkabau creation song activity can enrich the Minangkabau language's vocabulary, clarify the child's pronunciation in vocabulary pronunciation, expressing feelings and exploring the disclosure of children's ideas. The following is the data of the assessment of the implementation of the action on the ability to speak the mother tongue. From the graph above shows the average achievement score to know the progress of the ability to speak the mother tongue on the cycle. The percentage of scores achieved by children is as follows: Al 84.38\%, Df 89.06\%, Gn 87.5\%, Fh 81.25\%, No. 79.69\%, Ft 67.19\%, $\mathrm{Na} 82.81 \%$, Fk $81.25 \%$, Nc 70.31\%, Sn 71.88\%, Af 78.13\%, Wn 79.69\%, Ap $78.13 \%$, Za 85.94\%, Vr 93.75\%, Mm 81.25\%, and Gz 78.13\%. And the average score reached $80.61 \%$. While the children who achieve a score above the average class as many as nine people. 
TCP

Pre-cyclus- Cylus I- Cyclus II

$100.00 \%$

$90.00 \%$

$80.00 \%$

$70.00 \%$

$60.00 \%$

$50.00 \%$

$40.00 \%$

$30.00 \%$

$20.00 \%$

$10.00 \%$

$0.00 \%$

\begin{tabular}{|l|l|l|l|l|l|l|l|l|l|l|l|l|l|l|l|} 
Al & Df & Gn & Fh & No & Ft & Na & Fk & Nc & Sn & Af & Wn & Ap & Za & Vr & Mm \\
\hline
\end{tabular}

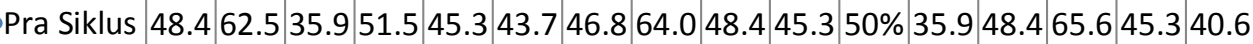

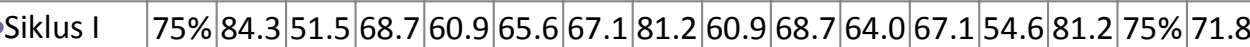

\begin{tabular}{l|l|l|l|l|l|l|l|l|l|l|l|l|l|l|l|l|l|} 
Siklus II & 84.3 & 92.1 & 87.5 & 85.9 & 81.2 & 82.8 & 85.9 & 90.6 & 73.4 & 79.6 & 84.3 & 82.8 & 79.6 & 89.0 & 93.7 & 82.8
\end{tabular}

Graphic 3: Graph of Outcome Results of Mother Language Language Speaking Ability In Cycle II

Based on the above graphics on improving the ability to speak the mother tongue on the 1st cycle is greater in experiencing the improvement that occurs in cycle 2 . Based on the visualization, the data obtained average increase in the ability to speak pre-cycle 1 st cycles of $19.21 \%$, while the increase cycle 1 - cycle 2 by $12.69 \%$. Thus the percentage increase that occurs pre-cycle up to cycle 2 of $31.90 \%$.

Based on the learning process activities using minangkabau creations songs there are some things that need to be considered so as to improve the ability to speak the mother language of the characteristics of children and songs created minangkabau creations in accordance with the ability of children. In the process of introducing songs creations Minangkabau provide opportunities for children to build understanding so that children are able to express their ideas. Minangkabau creations are useful because they contain elements of minangkabau language that can attract the attention of children to develop the ability to speak the mother tongue.

According to Kennet H. Pillips (1996: 71) suggests that: learning procedures using songs that are: 1) Directing children in two lines of simple songs or poems; 2) Introduction of word poetry; 3) Move to poem in one sentence; 4) Move to poem with two or three sentences; 5) Move to a very short song (two pharases), all sentences

The research put forward by Joan Bouza Koster (2012: 315) in the making of the song should pay attention to aspects of Break, Bridge, chord, lyrics and melodies that affect the creation of melodious sounding songs. The main purpose 
of applying a song creations is certainly to provide something fun to the child so that with something fun the child will be interested and gain experience learning through what they feel.

The song as a shaper of meaning, communication, and culture, builds a more complete musical understanding as a social and cultural practice. Music learning studies the technical aspects of singing such as awareness and sound development while singing. . In this action where the children follow the song creation activities Minangkabau that can improve the ability to speak the mother tongue is through group singing activities, in pairs and independent. The child is able to pronounce vocabulary and mentions vocabulary with proper minangkabau dialect (eg, tarimokasih, apologize). Research by Patrick D. Walton (2014: 54) suggests songs can strengthen phonology and word relationships in long-term memory, and act as memory aids when children are asked later to express words. Minangkabau creations created by special researchers for children group B is tailored to minangkabau culture and the characteristics of children group B. children like fun things like music for that teacher using keyboard instruments to add interesting minangkabau creations songs. Children feel excited and eager to follow every activity.

The speech development of children who engage in musical activity influences in a positive way and their sensitivity to rhythm increases. Instruments that the child uses in music activities and attempts to use his body with music contribute a lot to psychomotor development and influence his feelings of success and positive beliefs.

For that every teacher meeting creates an interesting song where the instrument of the song is different. Before singing a song creation minangkabau teachers do appersepsi to children it aims to reach the children's knowledge before the learning. In the process of participation of minangkabau creations song got elaborated are: The role of children in singing creations minangkabau songs. Every time the children's meetings always follow with enthusiasm, seen from the beginning of the activity until the final activity. In early child enthusiastic activities starting from marching and on core activities the child wants to follow the instruction according to the direction given by the teacher. While the activities cover children always provide Feed back (feedback) when the review activities.

Based on the results of quantitative data analysis obtained the percentage of total increase of observation of $35.66 \%$. This shows that there has been an increase in the percentage of the ability to speak the mother tongue of children on pre cycle, cycle I, and cycle II. The ability to speak the mother tongue is one of the most important and influential aspects of the development of other children's languages such as reading and writing.

At the pre cycle and end of cycle I, the percentage of observations has not been seen maximally. This is because children are not used to perform singing activities using musical instruments and minangkabau songs that involve a variety 
of indicators. The problematic indicator of pre-cycle, cycle I, and cycle II, as indicated by meaningful fluent vocabulary so that it can be understood, answers more complex questions, expresses feelings (angry, sad, happy, etc.) Expression while in and convey information from the activities undertaken in accordance with the understanding that it still needs stimulation through the help of images.

ased on the results of quantitative analysis also seen that, in the pre-cycle, cycle I, and cycle II Fk got the highest percentage of $64.06 \%$,. The lowest percentage gain in the pre-cycle $\mathrm{Gn}$ and $\mathrm{Wn}$ is 35.94. In cycle I the score obtained Fk equal to $81.25 \%$, Gn equal to $51.56 \%$, Wn equal to $67.19 \%$ while in cycle II obtained $\mathrm{Fk}$ equal to $90.63 \% \mathrm{Gn}$ equal to $87.5 \%$, Wn equal to $82.81 \%$. The percentage gain in each cycle is different. This can be influenced by internal and external factors such as congenital or hereditary factors, typical interest and characteristic factors, formation or environmental factors, maturity factors, and freedom factors.

At the highest score percentage gain in pre-cycle, cycle I, and cycle II that Fk ananda may be influenced by the supporting factors mentioned above. Based on heredity, such as can not be expressed as the main supporter because if looking at family background, FK comes from an educated family, his father works as an employee of one of the graduates S Bank, his mother is a lecturer with a background of $\mathrm{S} 2$. When viewed from interest factors $\mathrm{Wn}$ did have a great interest or interest in related activities express ideas. According to Fk teacher is one of the children who have good speech ability. FK parents do support and facilitate Fk's interests or preferences through storytelling activities through picture books, in addition to providing other learning facilities at home such as the stimulation of learning various media to develop the ability to speak Fk. Fk parents also often invite him to discuss or dialogue and accompany Fk when doing play or learning activities.

\section{CONCLUSION}

Based on the results of preliminary observations indicate there are some of the children whose ability to speak the mother tongue is still low. Based on the findings and discussion, the results of this study can be summarized as follows: (1) The process of activities to improve the ability to speak the mother tongue through the song creation activities Minangkabau. Giving action activities Minangkabau creations on group B TK Nurul Hidayah through several stages of the initial activities, core activities, and closing activities. The stage is a series of process of Minangkabau creation songs. (2) Learning strategy through Minangkabau creations, this activity uses keyboard media and image media used for Minangkabau creations, such as transportation drawings, profession. The activity of Minangkabau creations is an activity that involves the ability to speak the mother tongue of the child. 
This success was also supported from the results of anallisis pre-cycle data with the acquisition of TCP percentage of $48.71 \%$ in cycle I of $67.92 \%$ and in cycle II to $84.38 \%$. As agreed with the collaborators that this study is said to succeed if 12 of 17 who have succeeded according to Mills $71 \%$, are in the category developed according to expectations (BSH) and in this study 12 children have reached the category developed according to expectations (BSH). The results obtained show the developmental achievement level (TCP) of the ability to speak the mother tongue that has reached the expected criteria. Thus based on the conclusions that have been described previously it can be concluded that the giving of action in the form of "Minangkabau creations songs can improve the ability to speak the mother of children in group B TK Nurul Hidayah.

\section{REFERENCE}

Arslan, Derya. (2015). "First Grade Teachers Teach Reading With Songs," Journal of Humanities and Social Sciences, Vol. 20, July.

Gaies, Stephen J. (2013). “ESL Teachers' Classroom Speech.” Paper presented at the Sixth Annual Conference of the New York State English to Speakers of Other Languages and Bilingual Education Association, Albany, N.Y.

Gina, dkk. (2012). "Penggunaan Kato Nan Ampek Sebagai Komunikasi Nonverbal Dalam Komunikasi Antar Budaya Mahasiswa Minangkabau Perantauan.” Jurnal Eproc, Vol. 1, September.

Gul, Gulnihal. (2015). "The Efficiency of The Song Repertoire on The Musical Development Level of Pre-School Children Aged Six Years Old." Uludag Universitesi Egitim Fakultesi Guzel Sanatlar Egitimi Bolumu Muzik Egitimi Ana Bilim Dalı Journal, Vol 05, February.

Jariene, Raimonda and Vilija Saliene. (2014). "Speaking as Prerequisite To Socialisation In The General Curriculum Of The Lithuanian Language Education (as Mother Tongue)." Journal of Education, Vol. 116, September.

Kemmis, Stephen. (2000). The Action Reseach Planner. New York: Spinger.

Kostelecka, Yvona. (2014). "The Unidentifiable: Children of Czech Citizens Whose Mother Tongue is not Czech." Journal of Education, December.

Koster, Joan Bouza. (2012). Growing Artist Teaching The Art To Young Children. New York: Wadworth.

Kusumah, Wijaya \& Dedi Dwitagama. (2001). Mengenal Penelitian Tindakan Kelas. Jakarta: Indeks.

Lartecel, Jane K. (2014). "Strategies and Problems Encountered by Teachers in Implementing Mother Tongue - Based Instruction in a Multilingual Classroom." The IAFOR Journal of Language Learning. Vol.1, Winter.

Liao,Mei-Ying. (2013). "An Analysis Of Song-Leading By Kindergarten Teachers In Taiwan And The USA." Music Education Research, Vol. 16, September.

Lino, Dalila. (2016). "Early Childhood Education: Key Competences In Teacher Education." Polytechnic Institute Of Lisbon, Higher School of Education, Vol 6, Oktober. 
Mills, Geoffrey E. (2007). Action Reseach A Guide for The Teacher Researcher. New York: Pearson.

Montgomery, Amanda P. (2014). "Together in Song: Building Literacy Relationships with Song-based Picture Books." Language and Literacy, Vol. 16.

Moussay, Gerard. (1998). Tata Bahasa Minangkabau. Jakarta: Gramedia.

Navis, A. (1984). Alam Terkembang jadi Guru. Jakarta: PT Grafiti Pers.

Niland, Amanda. (2012). "Exploring the Lives of Songs in the Context of Young Children's Musical Cultures." Journal of Education, Vol. 10.

Philiph, Kiet. (2014). Teacing Kids to Sing. New York: Thomson Learning.

Priska. (2013). "Fenomena Sosial Masyarakat Minangkabau Dalam Lirik Lagu Ciptaan Agus Taher." Portal Garuda, September.

Seefeldt ,Carol \& Barbara A. Wasik. (2008). Pendidikan Anak Usia Dini. Jakarta: Indeks.

Vulchanova, Mila. (2014). "Links Between Phonological Memory, First Language Competence And Second Language Competence In 10-Year-Old Children." Journal of Education, Vol 07, July.

Walton, Patrick D. (2014). "Using Singing and Movement to Teach Pre-reading Skills and Word Reading to Kindergarten Children." An Exploratory Study, Volume 16, Issue 3, July.

Yazici, Zaliha. (2010). "How Bilingual Is Bilingual? Mother Tounge Proficiency and Learning Through A Second Language." Journal of Education and Scieces, Vol 8, November.

Yazid,Tantri Puspita. (2014). "Representasi Perempuan Minangkabau dalam Lirik Lagu si Nona." Jurnal PARALLELA, Vol. 1, Desember.

Zulkarnaini. (2003). Minangkabau Ra nah Nan Den Cinto. Bukittinggi: Usaha Iklas. 